\section{$\frac{409 / 1 / 179}{12 / 19}$}

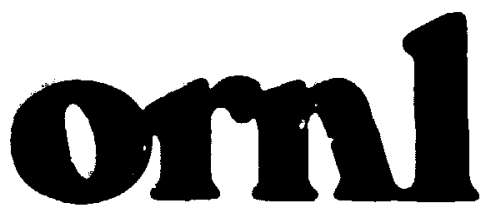

OAK

RIDGE

NATIONAL

IABORATORY

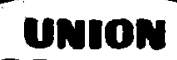

cARBIDE
$14.37 \%$

ORNL-5528

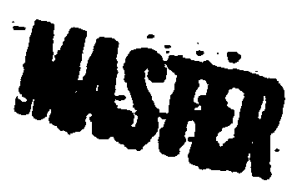

\title{
The Uncertainty Associated with Selected Environmental Transport Models
}

\author{
C. A. Little \\ C. W. Miller
}

Whatel er

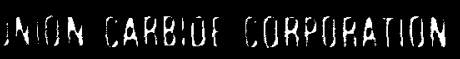
STH SHF IJNTEO STATES

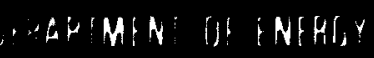

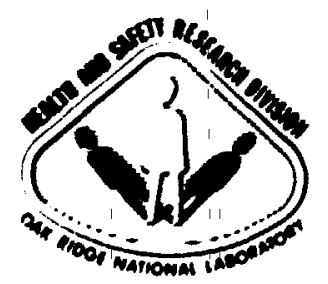

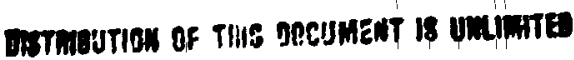


ORNL-5528

Dist. Categories UC-11

UC-41, UC-79p

Contract No. W-7405-eng-26

Health and Safety Research Division

THE UNCERTAINTY ASSOCIATED WITH SELECTED

ENVIROMENTAL TRANSPORT MODELS

C. A. Little

and

c. H. Miller

Date Published: November 1979

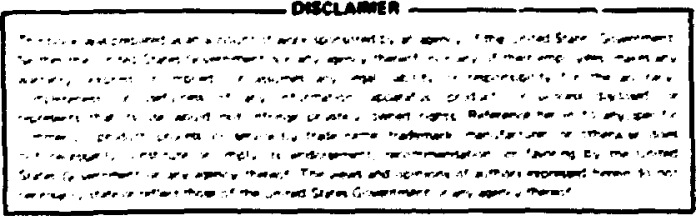

OAK RIDGE NATIONAL LABORATORY

Oak Ridge, Tennessee 37830 operated by

UNION CARBIDE CORPORATION

for the

DEPARTMENT OF ENERGY 
CONTENTS

Page

List of figures..................... iv

List of Tables....................... v

Highlights. . . . . . . . . . . . . . . . . vii

1. Introduction. .................... 1

2. Aquatic Transporı Models. ................. 2

2.1 One-dimensional models ................ 2

2.2 Longitudinal-Vertical Models .............. 6

2.3 Long tudinal-Transverse Models ............. 11

3. Atmospheric Dispersion. ................ 14

3.1 The Gaussian Plume Model .............. 16

3.2 Overall Uncertainties in Gaussian Mordel Calculations . . 18

3.2.1. Centerline Concentrations. ......... 20

3.2.2. Specific Hour and Receptor .......... 20

3.2.3. Ensemble Ave ages. . . . . . . . . . . . 22

3.2.4. Long Distanc-s.............. 22

3.2.5. Complex Ter 1 and Meteorology. ........ 24

3.2.6. Low Wind Spect, Inversion Conditions . . . . . . 24

3.3 Other Atmospheric Dispersion Models. . . . . . . . . 27

3.3.1. Trajectory Models.............. 27

3.3.2. Particle-in-cell Models. . . . . . . . . 29

3.3.3. Grid Models............... 29

4. Food Chain Models................. 30

4.1 Aquatic Food Chain Mod:is. ............ 30

4.2 Terrestrial Food Chain Models. ........... 36

5. Summary and Conclusions ................ 39

5.1 Aquatic Transport Models .............. 39

5.2 Atmospheric Transport Models ............. . 40

5.3 Food Chain Models. ................ 41

6. References. . . . . . . . . . . . . . . . 42 


\section{LIJT OF FIGURES}

Page

1. Experimental data and dispersed flow model ........... 5

2. Longitudinal disłrjbution of total $137 \mathrm{Cs}$, dissolved ${ }^{137} \mathrm{Cs}$, and particulate ${ }^{3} \mathrm{Cs}_{\mathrm{S}}$ in the Clinch River........... 10

3. Comparison of observed ano calculated transverse temperature distributions, the North Platte River near Glenrock, Wyoming, January $1970 . \ldots . . . . . . . . .$. 


\section{LIJT OF TABLES}

Page

1. Comparisons of maximum prediction with maximum obsorvation of $85 \mathrm{Sr}$ concentration in water of the experimental tiume....4

2. Comparison of maximum predicted and maximum observed of $197_{\mathrm{Hg}}$ in water.................... 7

3. Maximum differences between predictions of SERATRA model and observed concentrations. . . . . . . . . . . . 9

4. Ratios of FETRA predictions to observed values at the joint of largest discrepancy in the James River Estuary. ...... 15

5. An estimate of the uncertainty associated with concentration predictions made by the Gaussian plume atmospheric dispersion modei....................... 19

6. Some validation results for short-term Gaussian plume model predictions. .................. 21

7. Som validation results for ensemble averages predicted by the Gaussian plume model ................ . 23

8. Validation results for Gaussian plume model predictions out to $140 \mathrm{~km} . \ldots . \ldots 25$

9. Scme validation results for Gaussian plume model predictions in both complex terrain and also under low wind speed, inversion conditions.............. 26

10. Validation results for selected non-Gaussian atriospheric dispersion models....................... 28 
HIGHLIGHTS

C. A. Little and C. H. Miller. 1979. The Uncertainty Associated with Selected Environmental Transport Models. ORNL-5528. Uak Ridge National Laboracory, Oak Ridge, Tennessee.

This report describes the capabilities of several modeis to predict accurately either po!lutant concentrations in environmental media or radiological dose to human organs. The models are discussed in three sections: aquatic or surface water transport models, atmospheric transport models, and terrestrial and aquatic food chain models. Using data published primarily by model users, model predictions are comrared to observations. This procedure is infeasible for food chain mo'els and, therefore, the uncertainty embodied in the models input parameters, rather than the model output, is estimated.

Aquatic transport models are divided into one-dimensional, longitudinalvertical and longitudinal-horizoistal models. The or -dimensional models considered predict otservied concentrations to within a factor of 2 , but they underpredicted in a research flume and overpredicted in a natural environment. Longitudinal-transverse models were available with and without sorption. The sorption model, FETRA, underpredicted poliutant concentrations by $40 \%$ and sediment concentrations by $70 \%$. The nonsorption model, devised by Yotsukura and co-workers, was a, ., to predict temperature to within $1^{\circ} \mathrm{C}$ downstream from a nuclear power plant thermal ef.luent.

The atmospheric secition of the report draws severa? conclusions about the ability of the Gaussian plume atmospheric dispersicn model to predict accurately downwind air concentrations from releases under 
several sets of conditions. Data are cited to corroborate scientific judgments published. elsewhere. Predictions of ground-level centerline concentrations within $10 \mathrm{~km}$ of a continuous point release could be within 20\% of the observation. Predictions of concentration at a specific time and place within $10 \mathrm{~km}$ over flat terrain from the release point under steady meteorological condicions could be within an order of magnitude of the observations. The long-term average for a specific point up to $10 \mathrm{~km}$ from the release over flat terrain could be predicted within a factor of 2 . Monthly and seasonal averages over flat terrain up to $100 \mathrm{~km}$ away from the release could be predicted to wit.... a factor of 4. The uncertainties of predicting over complex terrain or during complex meteorology are unquantifiable at this point.

The section on food chain models concludes that no validation study has been conducted to test the predictions of either asuatic or terrestrial food chain models. Using the aquatic pathway from water to fish to an adult for ${ }^{137} \mathrm{Cs}$ as an example, a $95 \%$ one-tailed confidence limit interval for the predicted exposure is calculated hy examining the distributions of the input parameters. Such an interval is found to be 16 times the value of the median exposure. A similar one-tailed limit for the air-grass-cow-milk-thyroid for ${ }^{131_{I}}$ and infants was 5.6 times the median dose.

In conclusion, of the three model types discussed in this report, the aquatic transport'models appear to so the best job of precicting olierved concentrations. However, this conclusion is based on many fewer aquatic validation data than were available for atmospheric model 
validation. Atmospheric models can predict to within a factor of 2 under favorable conditions, but may be unsuitable for prediction under complex conditions. Food chain models have not been successfully validated and, therefore, uncertainty about the output of such models can presently oniy be quantified by analyzing the variance of the input parameters. 


\section{INTRODUCTION}

Numerous standards and regulations have beer: enacted to protect humans and the environment from releases of potentially hazardous substances. Models that predict the fate of these releases in given environmantal media are often used to ascertain whether or not the pertinent regulations are or will be violated. Such models are utilitarian because their predictions may be much easier to generate than a correspording set of field measurements. Unfortunately for model users, a model is never a completely accurate reflection of the actual system being modeled; consequently, mcdel predictions are never totally accurate indicators of the corresponding field measurement of the given quantity being predicted or measured. This difference between model predictions and the measured quantity can be termed rodel uncertainty.

It is the purpose of this report to examine the question, "How well can various types of models of transport through the environment predict what is observed?" In addressing this question, we have (1) relied heavily on published comparisons of predictions versus measurements for given models, (2) utilized scientific judgement in several cases, (3) consulted the results of a worksnop on "The Evaluation of Models Used for the Environmental Assessment of Radionuclide Releases" that was held in Gatlinburg, Tennessee, in September of 1977 (ref. 1). The present report is not intended to be a comprehensive review of environmental transport models.

The types of models that are considered include aquatic or surface water transport models, atmospheric transport models; and food chain models. 


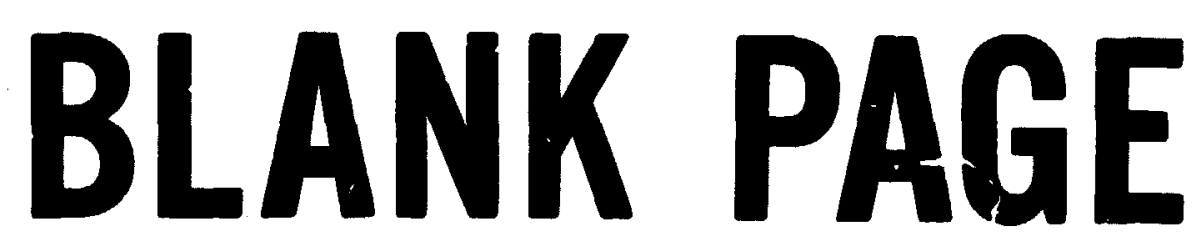


The foodrhain models include the aquatic foodchain (ingestion of fish) and the terrestrial foodchain (ingestion of fcod crops).

\section{AQUATIC TRANSPORT MODELS}

The term "aquatic transport models" used in this section will be takell to mean modeis uf the mass transport of some substance in and through some surface water system. Numerous aquatic transport models have been devised for myriad purposes and applications. Howterer, very few attempts at validation have been made and, of tha models which have been subjerted $t$ : validation attempts, an even smaller number have been tested for more than one locale or situation.

This section will expiore several aquatic transport moceis and any known atteinpts to validate those models. As stated in the introductory section, the selected models are intended to be neither a comprehensive ijsting nor a recresentative sampling of aquatic transport models. Pather, this section, as those that follow, estimates the degree to which the chosen models have been "alidated and attempts to place confidence bounds on the predictions of the various models.

The models will be grouped and discussed in three categories: one-

dimensional models, two-dimensiona! (longitudinal-vertical) models, and two-dimensional (longitudinal-transverse; models. In each of these tinree groups, models with and without the ability to consider sorption by sediment will be discussed.

\subsection{One-dimensiona? Models}

Gioyna and others at the Center for Research in Water Resources of the University of Texas at Austin have considered aquatic models 
that include both sorptive and furely hydrodynamic processes in a research flume (model river). According to Gloyria et al. ${ }^{2}$ one-dimensional models without sorption have been acceptably validated for the diffusive period after release, paricially validated for the convective poriod, and not validated $\mathrm{fi}_{\mathrm{I}}$ - dead water zones.

Shih and Gloyna ${ }^{3}$ validated a one-dimensional analytic solution to the convective-dispersive equation for transport of ${ }^{85} \mathrm{Sr}$ in their experimental flume. We interpolated from figures of predicted and observed concenirations to calculate the ratios si naximum prediction to maximum observacion shown in Table 1. For the five curves published, the model of inih and Gloyna ${ }^{3}$ tended to underpredict the maximum concentration of 35 sr observed in the water (Fig. 1). However, the smallest value of the ratio of maximum prediction to maximum observatior. was only 0.66 . In other words, the iargest underprediction amounted to only about $50 \%$. If this trend were to hold true, we would expect that the model of Shih and Gloyna would be arceptable for llany applications. Approximately the same ability to predict solute concentrations was observed in similar studies with ${ }^{85} \mathrm{Sr}$ in the research flume at the University of Texas. 4 Unfortunately, to our knowledge Gloyna has not tested his model outside the experimental flume.

However, Raridon et al. 5 modified the model of Shih and Gloyna and tested its ability to predict mercury transport in the Walker Branch watershed at Oak Ridge National Laboratory. Raridon et al. claimed that their changes in the Shih-Gloyna model more completely and realistically described the mechanism of sorption-desorption. Much as with the ShihGloyna model, we used the data plotted by Raridon et al. to estimate the ratio of the maximum mercury concentration predicted to that observed 
Table $1 \cdot 85$ Comparisons of maximum prediction with maximum observation of ${ }^{85} \mathrm{Sr}$ concentration in water of the experimental flume

\begin{tabular}{|c|c|c|c|}
\hline \multirow{2}{*}{$\begin{array}{l}\text { Downstream } \\
\text { distance, } \mathrm{ft}\end{array}$} & \multicolumn{3}{|c|}{ Maximum value $\left({ }^{85} \mathrm{Sr} \mathrm{dpm} / \mathrm{ml}\right)$} \\
\hline & Predicted & Observed & Predicted/0bserved \\
\hline $\begin{array}{r}50 \\
50 \\
90 \\
90 \\
170\end{array}$ & $\begin{array}{r}1000 \\
1500 \\
790 \\
1200 \\
560\end{array}$ & $\begin{array}{r}1500 \\
1510 \\
1200 \\
1230 \\
770\end{array}$ & $\begin{array}{l}0.67 \\
0.99 \\
0.66 \\
0.98 \\
0.72\end{array}$ \\
\hline
\end{tabular}

${ }^{a}$ C. S. Shih and E. F. Gloyna, kadioactivity Transport in waterMathematical Model for the Transport of Radionuclides, CRWR-18, Center for Research in Water Resources, The University of Texas, Austin, Texas, June 1, 1967. 


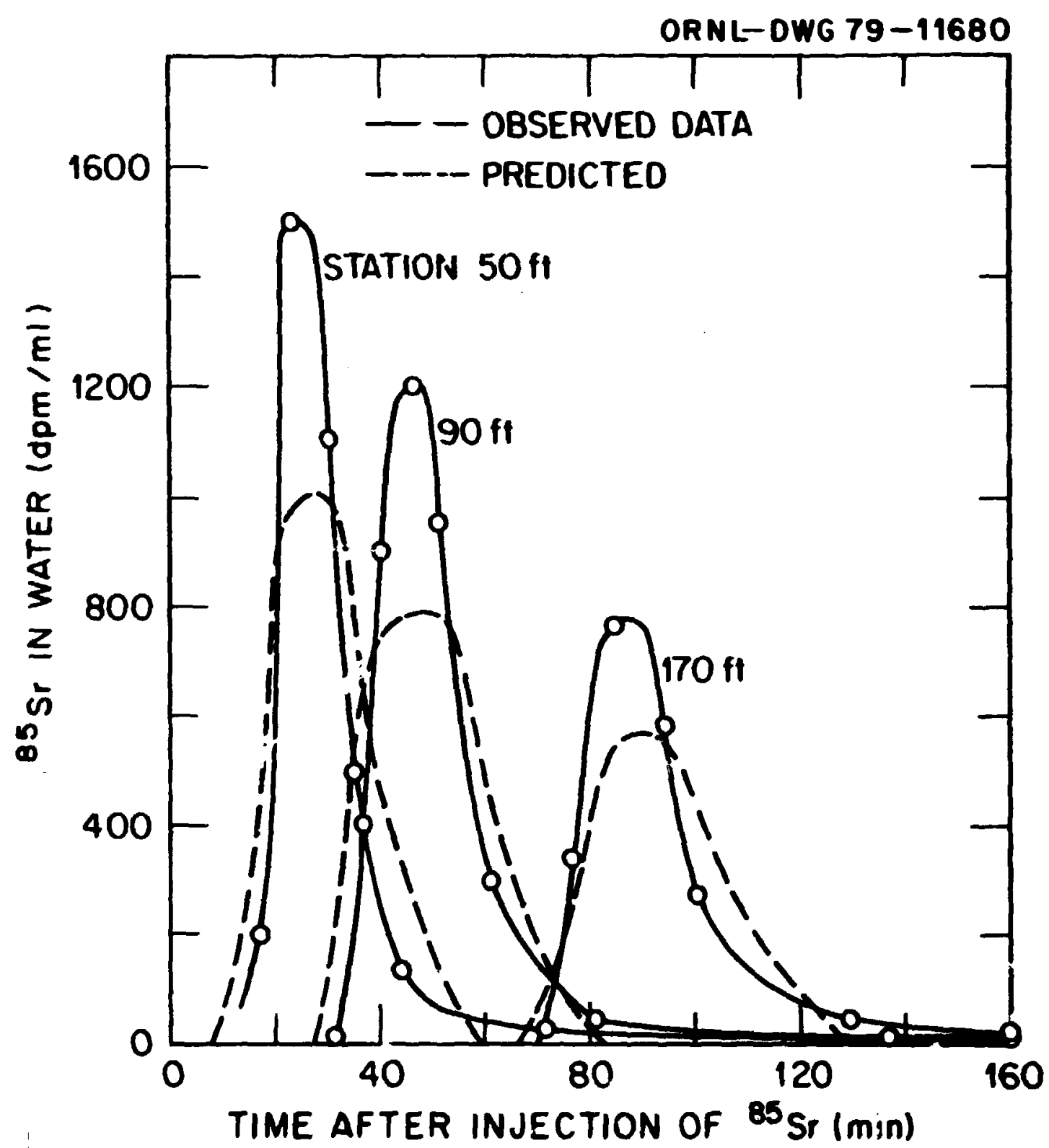

Fig. 1. Experimental data and dispersed flow model. Source: C. S. Shih and E. F. Gloyna, Radioactivity Tranoport in Water-Mathematical Model for the Transpont of Radionuclides, CRWR-18, Center for Research in Water Resources, The University of Texas, Austin, Texas, June 1, 1967. 
(Table 2). The nost obvious characteristic of th: Paridon et al. predictions in Table 2 is that the model tended to overpredict the observed concentrations rather than underpredict as was the case with Shih and Gloyna (Table ?). However, as with Shih and Gloyna, Raridon's predictions were less than a factor of 2 different from the observations. This result would tend to indicate that the Stih-Gloyna riodel car. predict adequaiely the transport of some pollutant in a stream other than the University of Texas research flume. This conclusion must be qualified by the reminder that Raridon et al. only reported samples to a downstream distance of $100 \mathrm{~m}$. Whether the model would continue to periorm arequately at longer distances remains to be seen.

in summary, the primary one-dimensional model is one developed by Gloyna and his associates at the University of Texas. This model can predict observed concentrations in an experimental flume within a factor of 2 , but the mudel tends to underpredict. Raridon et a1. ${ }^{5}$ adapted the Shih-Gloyna model for use in a natural stream. Mercury concentrations were predicted within a factor of 2 to distances $u$ to $100 \mathrm{~m}$ downstream, but the model tended to overpredict rather than to underpredict.

\subsection{Longitudinal-Vertical Models}

We are aware of no longitudinal aquatic radioactivity transport models tnat do not incorporate sorption. The SERATRA ${ }^{6,7}$ model developed by Onishi at Battelle-Pacific Northwest Laboratory has some success in predicting the conceritrations of several nuclides in both water and sediment of several itreams. The SERATRA is a finite element sediment 
Table 2. Comparison of maximum predicted and maximum observed
of

\begin{tabular}{|c|c|c|c|}
\hline \multirow{2}{*}{$\begin{array}{l}\text { Downstream } \\
\text { distance, m }\end{array}$} & \multicolumn{3}{|c|}{ Maximum value $\left({ }^{197} \mathrm{Hg}\right.$ inCi/liter) } \\
\hline & Predicted & Observed & Predictea/ubserved \\
\hline $\begin{array}{r}10 \\
20 \\
40 \\
70 \\
100\end{array}$ & $\begin{array}{c}13.9 \\
12.4 \\
10.0 \\
6.37 \\
4.67\end{array}$ & $\begin{array}{c}12.5 \\
10.6 \\
5.99 \\
5.67 \\
4.03\end{array}$ & $\begin{array}{l}1.11 \\
1.17 \\
1.67 \\
1.12 \\
1.16\end{array}$ \\
\hline
\end{tabular}

$a_{R}$. J. Raridon, M. T. Mills, and J. H. Huckabee, Computer Model for Chemical Exchange in the Stream System, Pp. 284-291 in Proceedings of the First Annual ISF Trace Contaminants Conference, Oak Ridge Natianal Laboratory, Aumust 8-10, 1973, CONF-73n802, 1973. 
and contaminant model, which was modified to predict time-dependent longitudinal and vertical distributions of sediments and radionuclides in both the Columbia and $\mathrm{Clinch}$ rivers. For the $\mathrm{Clinch}$ River study (ref. 6), ${ }^{137} \mathrm{Cs},{ }^{90} \mathrm{Sr}$, and ${ }^{198_{\mathrm{Au}}}$ were used as sources at least partly because data from previous sampling of the river were available. According to Onishi", "agreement of predictef results and field data for continuous release cases was very good, winile for instantaneous releases agreement was poor." In the Colımbia River verification study (ref. 7), ${ }^{65}$ In was traced because of its adsorption characteristics and again because field data were available. As in the Clinch River study, Onishi ${ }^{7}$ stated that for the Columbia River "sediment and radionuclide results or the verificaticn test case... indicate very good agreement with measured data." Both the quoted statements are true enough; the field data on radionuclide concentrations in water presented by 0 nishi ${ }^{6,7}$ do agree fairly well with the predictions of the models (Table 3 ). The largest discrepancy was the underprediction of the observed concentration by more than a factor of 4 , which occurred with ${ }^{137}$ Cs in Case 1. Unfortunately, the small number of field observatir is that Onishi presented for each case make it difficult to ducide whether the predictions are or a.e not in agreement with the measurements. The data in Fig. 2 are indicative of this fact. 
Table 3. Maximum differences between predictions of SERATRA model and observed concentrations ${ }^{\alpha}$

\begin{tabular}{lcccc}
\hline Nuclide & Distance, $\mathrm{km}$ & $\begin{array}{c}\text { Dissolved concentration/liter } \\
\text { Prediction }\end{array}$ & $\begin{array}{c}\text { Prediction/ } \\
\text { Observation }\end{array}$ \\
\hline${ }^{137} \mathrm{Cs}$ & 13 & 2.1 & 1.0 & 2.1 \\
${ }^{137} \mathrm{Cs}$ & 30 & 3.7 & 1.0 & 1.0 \\
${ }^{90} \mathrm{Sr}$ & 13 & 2.8 & 3.7 & 1.0 \\
${ }^{90} \mathrm{Sr}$ & 30 & 41 & 2.8 & 1.0 \\
${ }^{65} \mathrm{Zn}$ & 108 & 41 &
\end{tabular}

${ }^{2}$. Onishi, Finite Element Models for Sediment and Contominant Transport in Surface Waters-Transport of Sediments and Radionuclides in the Clinch River, BNWL-2227, July 1977; Mathematical Simulation of Sediment and Radionuclide Transport in the Colrombia River, BNWL-2228, August 1977. 


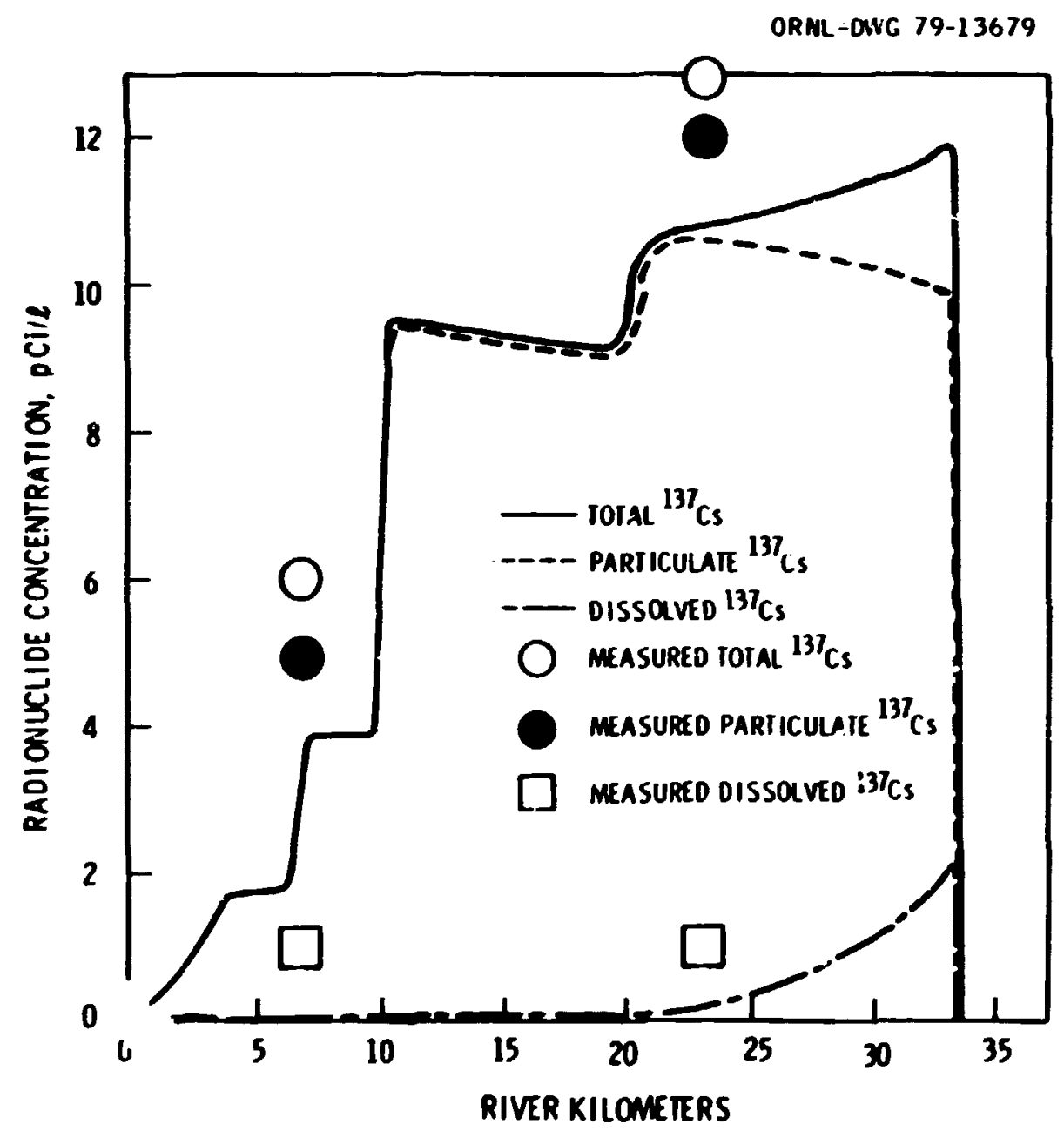

Fig. 2. Longitudinal distribution of total ${ }^{137} \mathrm{Cs}$, dissolved ${ }^{137} \mathrm{Cs}$, and particulate ${ }^{137} \mathrm{Cs}$ in the Clinch River. Source: $Y$. Onishi, D. L. Schreiber and R. B. Codell, Mathematical Simuation of Sediment and Radionuclide Transport in the Clinch River, Tennessee, Proceedings of the ACS/CSJ Chemical Congress, Honolulu, Hawaii, April 2-6, 1979 (Ann Arbor Science Publications, Inc.). 


\subsection{Longitudinal-Transverse Model:}

The aquatic transport models of Yotsukura and $\operatorname{Cobb}^{8}$ and Yotsukura and Sayre ${ }^{9}$ were concerned with transverse mixing of solutes in streams. A later paper by Jackman and Yotsukura ${ }^{10}$ adapted the model of Yotsukura and Cobb to predict temperature downstream from some thermal input. Yotsukura and Sayre ${ }^{9}$ offered a mathematical proof that the transverse cumulative discharge concept could be included in the steady-state twodimensional mixing equation while stili incorporating the important transverse velocity term. Yotsukura ard Sayre ${ }^{9}$ ultimately derived a simpler form of the convection-diffusion equation that was particularly applicable to nonuniform channels.

All of the models discussed by Yotsukura and his co-workers $8-10$ employed an orthogonal curvilinear coordinate system to describe the geometrical configuration of the channel. This coordinate system coupled with the flow distribution within it allowed the easy inclusion of the effects of channel irregularities and curvature.

Although both Yotsukura and $\operatorname{Cobb}^{8}$ and Yotsukura and Sayre ${ }^{9}$ published curves of observed and predicted concentration profiles, the agreement between predictions and observations cannot be gauged from those data, because only the best curves of prediction were plotted. The "best" prediction curve resulted from varying the value of several input parameters and generating a group of predictions for each parameter value, (i.e., the model was tuned to fit the observations). Nevertheless, Yotsukura, Cobb and Sayre felt that this process "verified" their mode? because the parameters being varied resulted in an average diffusion 
coefficient that was uniform for a given test and that was bracketed by published values.

The adaptation of the Yotsukura-Sayre model by Jackman and Yotsukura 10 included equations for the conservation of themal energy. The transverse temperature gradient downstream from a site of thermal input was modeled for several different rivers. Contrary to the earlier published results, 8,9 the curves published in the temperature study ${ }^{10}$ did not result from a tuning of the model.

The curves of predicted temperature versus observed temperature were generally very similar. In no case did the predicted temperature exceed the observed temperature by as much as $2^{\circ} \mathrm{C}$. One of the cases of poorest agreerrent is shown in Fig. 3 for time 0805 . Most of the predictedobserved curves showed even better agreemenc. In spite of the good agreement, the data of Jackman and Yotsukura ${ }^{10}$ are frustrating, because the uncertainty is difficult to quantify. Contrary to studies where discrete concentrations are predicted, a mean ratio of predicted to observed concentrations has little meaning for Celsius degrees; an average overprediction of $1{ }^{\circ} \mathrm{C}$ seems trivial if the observed concentration is large, but seems absurd if the observation is near zero. Translation of the Celsius data into dagrees Kelvin creates the inverse problem-a near perfect model; variations of a few degrees in the Kelvin scale would seem very minor. Therefore, making a quantitative statement about the ability of the Jackman-Yotsukura model to predict solute concentrations downstream from some release is difficult to do. Suffice it to say that the model of Yotsukura and Sayre ${ }^{9}$ is good enlough to have been suggested by the $M R C^{11}$ as an appropriate inodel to use for routine or continuous releases from nuclear power plants. 


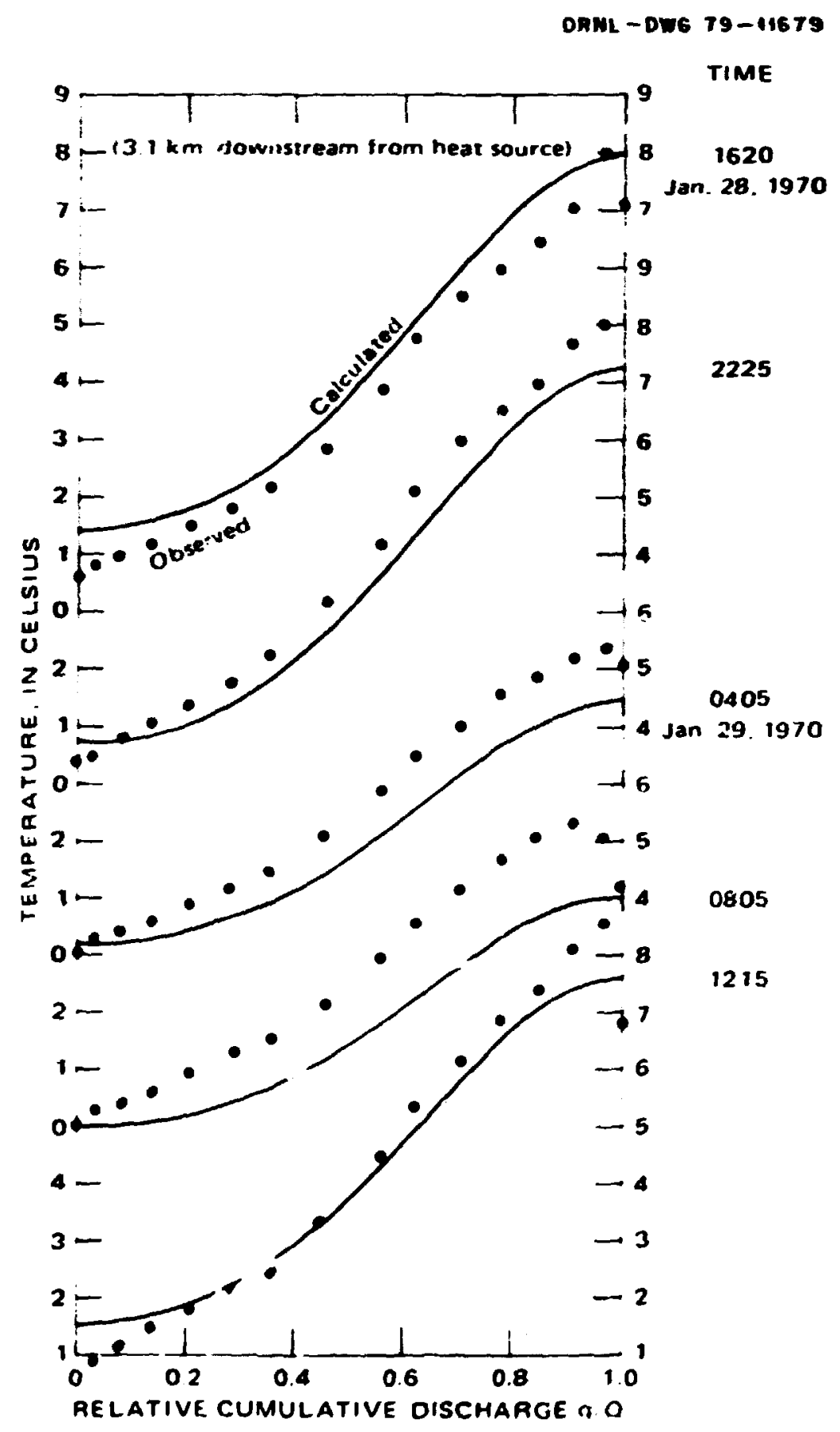

Fig. 3. Comparison of observed and calculated transverse temperature distributions, the North Platte River near Glenrock, Hyoming, January 1970. Source: A. P. Jackmon and N. Yotsukura, Thermal Loading of Natura? Streams, U.S. Geolngical Survey Professional Paper 991, U.S. Government Printing Office, Washington, D.C., 1977. 
The model FETRA developed by Onishi and others ${ }^{12-14}$ differs from the Yotsukurz-Sayre model by virtue of a capbility to consider sorption. Although FETRA has not been applied to any radiological assessments, it has been used to predict the transport of sediment and the pollutant kepone in the James River Estuary of eastern Virginia. The FETRA model consists of the three submodeis: (1) a sediment transport code, (2) a dissolved contaminant transport code, and (3) a particulate contaminant transport code. Data, which car be considered verification data, were given for sedirant transport and particulate kepone. 14 The data were pubtished in numerous figures of sediment or kepone concentration as a function of distance downstream in the James River. Onishi varied the simulation parameters between figures and compared the results. For each figure, we found the point of largest divergence between either predicted-average particuiate kepone and observed-average particulate kepone or predicted- and observed-total seciment concentation in water. For each point of largest discrepancy, we calculated the predicted to observed ratio as an indication of agreement (Table 4). The smal? est ratios of predicted tc observed-average particulate kepone concentration and predictiate sediment concentration were 0.63 and 0.33 , respectively. This means that FETRA underpredicted particulate kepone concentrations by about $40 \%$ and underpredicted sediment concentrations by nearly $70 \%$. Onishi and Wise ${ }^{14}$ gave no, field measurements for dissolved pollutant in this case.

\section{ATMOSPHERIC DISPERSION}

One of the principal ways in which radionuclides from nuclear facilities reach the environment is via discharges to the atmosphere. 
Table 4. Ratios of FETRA predictions to observed values at the point of largest discrepancy in the James River Fstuary ${ }^{a}$

\begin{tabular}{llll}
$\begin{array}{c}\text { Downstream } \\
\text { distance, } \mathrm{km}\end{array}$ & $\begin{array}{c}\text { Tide } \\
\text { type }\end{array}$ & $\begin{array}{c}\text { Concentration at the point } \\
\text { of largest discrepancy } \\
\text { Predicted }\end{array}$ & $\begin{array}{c}\text { Predicted/ } \\
\text { Observed }\end{array}$ \\
\hline
\end{tabular}

Average particulate kepone concentration in sediment $(\mu \mathrm{g} / \mathrm{g})$

$\begin{array}{rllll}101 & \text { Ebb } & 0.072 & 0.092 & 0.78 \\ 101 & \text { Slack } & 0.070 & 0.108 & 0.65 \\ 75 & \text { Flood } & 0.106 & 0.154 & 0.69 \\ 102 & \text { Average } & -0.068 & 0.106 & 0.64 \\ 101 & \text { Ebb } & 0.070 & 0.090 & 0.78 \\ 102 & \text { Slack } & 0.068 & 0.108 & 0.63 \\ 107 & \text { Flood } & 0.068 & 0.108 & 0.63 \\ 102 & \text { Average } & 0.07 & 0.106 & 0.66\end{array}$

Total sediment concentration in water ( $\mathrm{kg} / \mathrm{liter}$ )

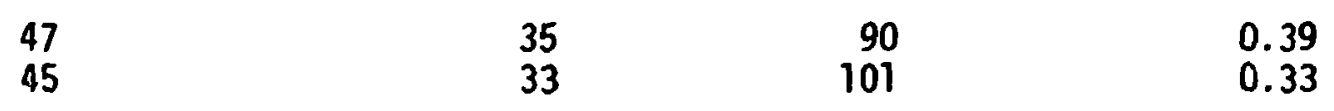

$a_{Y}$. Onishi and S. E. Wise, Mathematical Simulation of Transport of Sediment and Kepone in the James River Estuam, PNL-2731, September 1978. 
Atmospheric dispersion calculations provide estimates of air concentration resulting from these releases. These air concentrations are then used to calculate the dose to ran from both direr: allu indirect pathways. As a result, an estimate of the uncertainty associated with the atmospheric dispersion calculation is an important component in any attempt to estimate the uncertainty in the final dose calculation.

\subsection{The Gaussian Plume Model}

The Gaussian plume nodel ${ }^{15}$ is the most widely used method of estimating dowminid a ir concentrations of radionuciides released to the atmosphere. 16,17 Although this model has theoretical limitations, it rias proven reasonably successful in predicting observed air concentration patterns. 15

For a continuous point source, the model is given by

$$
x=\frac{Q}{\pi u \sigma_{y} \sigma_{z}} \exp \left[-1 / 2\left(\frac{H}{\sigma_{z}}\right)^{2}-1 / 2\left(\frac{y}{\sigma_{y}}\right)^{2}\right],
$$

where

$$
\begin{aligned}
X & =\text { grcund-level air concentration, } \mathrm{Ci} / \mathrm{m}^{3} ; \\
Q & =\text { release rate, } \mathrm{Ci} / \mathrm{sec} ; \\
H & =\text { height oi release, } \mathrm{m} ; \\
u & =\text { wina speed, } \mathrm{m} / \mathrm{sec} ; \\
\sigma_{y}, \sigma_{z} & =\begin{array}{l}
\text { standard deviation of a Gaussian distribution in the cross } \\
\text { wind and vertical directions, respectively, } \mathrm{m} .
\end{array}
\end{aligned}
$$

It has beel found that changes in $\sigma_{y}$ and $\sigma_{z}$ can greatly affect the resulting air concentration calculated by the model. ${ }^{18,19}$ A number of 
empirically determined graphs of $\sigma_{y}$ and $\sigma_{z}$ as a function of dowmind distance and atmospheric staoiiity have been proposed. 20 Vogt $^{21}$ has compared the short-term diffusion factors $\frac{\chi U}{Q}(x, y=0, z=0)$ computed from six such sets of curves assuming a 100-m release height and using one method of determining atmospheric :taivility. He found that the maximum values generally agreed within a factor of 2 for each set of curves and each atmospheric stability category considered, but the location of the maxima differed by as much as an order of magnitude. Vogt $^{21}$ also calculated annual average diffusion factors using the same six sets of dispersion parameters and annual average meteorological statistics for Jiilich. In this case, the maximum vilues differed by over an order of magnitude and their location by a factor of 5 depending upon which set of dispersion parameters was used.

Vogt's comparisons were based on one method of determining the stability of the atmosphere. However, a variety of methods have been proposed for classifying the stability of the atmosphere. ${ }^{22}$ It has been shown that these different methods can give significantly different results when applied to the same meteorological data set. $23-25$ There are indications that the selection of a stability category alone can result in a factor of 4 difference between the lowest and highest annual average air concentration calculated using a given set of $\sigma_{y}$ and 'z curves. $23,24,26$ Because of the large differences in the value of the diffusion factor that can result from the use of different values of dispersion parameters, it has been recommended that as much sitespecific information as possible concerning wind velocity, topography, and release height be utflized when choosing values of $\sigma_{y}$ and $\sigma_{z}$ to be utilized in a givei situation. 22 
Another critical parameter in the Gaussian model is the height of the release, $H$. This value includes not only the physical height of the stack but also any additional height due to the rise of the plume ar a result of its buoyancy or momentum. The amont of this plume rise is usually estimated through the use of mudels such as those suggested by Briggs. 27 Nuclear power plants seldom have either large momentum or buoyant plumes or stacks associated with their routine releases so normally plume rise is not critical to the estimation of air concentrations resulting from these i.acilities. 26

\subsection{Overall Uncertainties in Gaussian Model Calculations}

The best way to determine the cverall uncertainty associated with atmospheric dispersion models such as the Gaussian plume model is to compare their predictions with environmental measurements taken under release conditions similar to those assumed by the model, a process commonly referred to as model validation. Such studies need to be conducted under a variety of terrain, release height, and meteorological conditions. Unfortunately, not enough modei validation studic have been performed to allow for a reliable statistical analysis of the uncertainty associated with the Gaussian plume model. 26,28-30 One attempt to estimate this uncertainty based largely on scientific judgment is summarized in Table 5 and discussed below. ${ }^{26}$ These estimates assume that the factors considered above, i.e., dispersion parameters, plume rise, etc., have been optimized. The comparisons between predictions and field measurements discussed below, however, need not ir.clude an optimization of these parameters in the prediction process. For example, selection oi a different set of dispersion parameters or a different criteria for determining atmospheric stability could change the results 
Table 5. An estimate of the uncertainty associated with concentration predictions made by the Gaussian plume atmospheric disperson mode ${ }^{a}$

\begin{tabular}{cc} 
Conditions & $\begin{array}{c}\text { Range of the ratio } \\
\text { Predicted } \\
\text { Observed }\end{array}$ \\
\hline
\end{tabular}

Highly instrumented flat-field site; ground$0.8-1.2$ level centerline concentration withir. $10 \mathrm{~km}$ of continuous point source

Specific hour and receptor point; flat $0.1-10$ terrain, steady meteorological conditions; within $10 \mathrm{~km}$ of release point

Ensemble average fcr a specific point, flat terrain, within $10 \mathrm{~km}$ of release point (such as monthly, seasonal, or annua? average)

Monthly and seasonal averages, flat terrain, $10-100 \mathrm{~km}$ downwind

Complex terrain or meteorology (e.g., sea breeze regimes)

$0.25-4$

$b$

$a_{T}$. V. Crawford (Chairperson), Atmospheric Transport of Radionuclides, Pp. 5-32 in Proceedings of a Workshop on the Evaluation of Models Used for the Environmental Assessment of Radionuclide Releases, ed. by F. C. Hoffman, D. L. Shaeffer, C. W. Miller, and C. T. Garten, Jr., USDUE Report CONF-770901, NTIS, April 1978.

${ }^{b}$ The group which assembled these estimates did not feel there was enough information available to make even a "scientific judgment" estimate under these conditions. 
of a given comparison. However, it is believed that these comparisons as given provide a usefui indication of the uncertainty in the Gaussian model to be expected under the stated conditions.

\subsubsection{Centerline cuncentrations}

The estimate given for the highly instrumented flat-field site assumes that previous data on meteorology and airborne concentrations are also available. Pasquill 18 has also estimated an uncertainty of $\pm 10-20 \%$ for short dowmind distances, steady winds, and ground-level releases. He suggests that an error of $\pm 30-35 \%$ may be more appropriate for elevated releases. A more appropriate value for the uncertainty associated with the maximum air concentration value from elevated sources

may be $\pm 50 \%$. 18,19 The meteorological and terrain conditions specified in these estimates are rather idealistic and seldom occur in the real world.

\subsubsection{Specific hour and receptor}

As shown in Table 6, the order of magnitude uncertainty in concentration estimates for a specific hour and receptor location is supported by recent comparisons based on data taken at Hanford, Washington, provided the wind diraction is accurately known. 25 The Hanford site is fairly representative of flat terrain, but these results are limited to thermally stable conditfons. Measurements taken under a larger variety of atmospheric stability conditions also support this uncertainty estimate, however. ${ }^{31}$ These latter results also indicate that for neutral and slightly stable conditions the uncertainty may be a factor of 2 or more less than what is estimated in Table 5. 
Table 6. Some validation results for short-term Gaussian plume model predictions

\begin{tabular}{lcc}
\hline \multicolumn{1}{c}{ Conditions } & $\begin{array}{c}\text { Range of the ratio } \\
\text { Predicted } \\
\text { Observed }\end{array}$ & Reference \\
\hline $\begin{array}{l}\text { Surface level releases of fluores- } \\
\text { cein particles under thermally } \\
\text { stable atmospheric conditions }\end{array}$ & $\begin{array}{c}0.2-5,72 \% \text { of } \\
\text { samples } \\
\text { at Hanford, Washington }\end{array}$ & 25 \\
$\begin{array}{l}\text { SF releases from a 36-m stack } \\
\text { under stability categories B } \\
\text { through F at the Rocky Mountain }\end{array}$ & $\begin{array}{c}0.33-3,89 \% \text { of } \\
\text { samples } \\
\text { Arsenal, Denver, Colorado }\end{array}$ & $\begin{array}{c}0.1-10,100 \% \text { of } \\
\text { samples }\end{array}$ \\
\hline
\end{tabular}




\subsubsection{Ensemble averages}

In radiological assessments one is generally more interested ir. ensemble averages than single receptor values when considering routine releases from nuclear facilities. Table 5 indicates that for flat terrain the uncertainty associated witr ensemble averages is expected to be significantly less than the uncertainty associated with predictions for a specific location. Recent validation studies 32,33 indicate that such accuracy is possible even in more complex terrain when meteornlogical regimes are well defined (Table 7 ).

One way in which air concentrations are used in radiologica! assessments is to estimate external exposure to man fron airborne radionuclides. Monthly and annual average exposures measured around operating nuclear power plants have been compared to exposures predicted from air concentrations calculated from the Gaussian plume model. 34-36 While the exposure model as well as the air concentration model is involved in the final comparison, on the average the predicted values were within a factor of 2 of measured exposures, and individual station predictions were all within a factor of 5 of measurements (Table 7).

\subsubsection{Long distances}

Most atmospherfc validation studies have been carried out for downwind distances on the order of $10 \mathrm{~km}$ or less. Radiological assessments, however, are generally carried out to distances approaching $100 \mathrm{~km}$ or more. Recently, a data set consisting of ${ }^{85} \mathrm{Kr}$ release information for the Savannah River $P 1$ ant and concurrent ${ }^{85} \mathrm{Kr}$ air concentration measurements out to a distance of $150 \mathrm{~km}$ has become avaflable. $i^{37}$ Comparisons using 
Table 7. Some validation results for ensemble averages predicted by the Gaussian plume model

\begin{tabular}{|c|c|c|}
\hline Conditions & $\begin{array}{l}\text { Range of the ratio } \\
\text { Predicted } \\
\text { Observed }\end{array}$ & Reference \\
\hline $\begin{array}{l}\text { Annual average } \mathrm{SO}_{2} \text { concentrations } \\
\text { for Roane } \mathrm{Co} . \text {, Tennessee; both } \\
\text { point and area source emissions } \\
\text { included }\end{array}$ & $0.5-\leq 2$ & 32,33 \\
\hline $\begin{array}{l}\text { Continuous gamma-ray measurements } \\
0.04-6.8 \mathrm{~km} \text { downwind of a } \\
\text { boiling water reactor }\end{array}$ & $0.33-1.78$ & 34 \\
\hline $\begin{array}{l}\text { Gamma-ray doses dowiwind of } \\
\text { Humboldt Bay Nuclear Power Plant }\end{array}$ & $0.5-\leq 2$ & 35 \\
\hline $\begin{array}{l}\text { Monthly gamma-ray doses for four } \\
\text { stations downwind of a nuclear power } \\
\text { plant at an inland site }\end{array}$ & $\begin{array}{l}0.30-4.78 \text {, } \\
\text { individud } 1 \text { stations } \\
1.55 \text {, mean of all } \\
\text { data }\end{array}$ & 35,36 \\
\hline
\end{tabular}


this data set (Table 8) support the uncertainty estimate shown in Table 5. $38-40$

\subsubsection{Complex terrain and meteorology}

The group which assembled the estimates shown in Table 5 did not feel there was enough information available to make even a "scientific judgment" estimate of the accuracy of the Gaussian plime model under these conditions. 26 The Gaussian model was never designed to be used under conditions of complex terrain or meteorology without extensive modification, at least of its input parameters.

Koch and his cn-workers ${ }^{29}$ have reviewed a number of diffusion experiments conducted in complex terrain (Table 9). On the average, the Gayssian modei tended to overpredict the measured concentrations by a factor of 5 near the source. However, some individual $5 \mathrm{~min} 5 \mathrm{O}_{2}$ concentrations were underestimated by as much as two orders of magnitude. Other maximum hourly $\mathrm{SO}_{2}$ concentrations were overpredicted by factors of 20 to nearly 300 . In general, the model was found to be mrsis accurate for flat terrain, less accurate for rugged, open terrain, and least accurate for a confined canyon.

\subsubsection{Low wind speed, inversion canditions}

A special condition not considered in Table 5 is dispersion under low wind speeds in the presence of a temperature inversion. Again, the Gaussian plume model was not designed to be used under these conditions.

Van der Hoven ${ }^{41}$ has reviewed several experílients conducted under these conditions for ground level sources (Table 9). All wind speeds were less than $2 \mathrm{~m} / \mathrm{sec}$, and the vertical temperature gradient was greater 
Table 8. Validation results for Gaussian plume model predictions out to $140 \mathrm{~km}$

\begin{tabular}{|c|c|c|}
\hline Conditions & $\begin{array}{l}\text { Range of the ratio } \\
\text { Predicted } \\
\text { Observed }\end{array}$ & Reference \\
\hline \multicolumn{3}{|l|}{$\begin{array}{l}25 \mathrm{Kr} \text { measurements } 30-140 \mathrm{~km} \text { dowmind } \\
\text { ^ } \mathrm{i} \text { the Savannah River Plant }\end{array}$} \\
\hline Heek?y and annual averages & $0.25-4$ & 38 \\
\hline Seasonal averages, spring & $\begin{array}{l}2-4,69 \% \text { of samples } \\
2-10,100 \% \text { of samples }\end{array}$ & 39 \\
\hline Summer & $\begin{array}{l}0.5-4,46 \% \text { of samples } \\
0.5-10,85 \% \text { of samples }\end{array}$ & \\
\hline Fall & $\begin{array}{l}0.5-4,31 \% \text { of samples } \\
0.5-10,85 \% \text { of samples }\end{array}$ & \\
\hline Hinter & $\begin{array}{l}2-4,69 \% \text { of samples } \\
2-10,92 \% \text { of samples }\end{array}$ & \\
\hline Annual average & $\begin{array}{l}1-4,77 \% \text { of samples } \\
1-10,92 \% \text { of samples }\end{array}$ & \\
\hline $\begin{array}{l}\text { 10-hour averages, six variations of } \\
\text { the model }\end{array}$ & $\begin{array}{l}0.5-2,42-65 \% \text { of sampl } \\
0.1-10,79-95 \% \text { of samp }\end{array}$ & $\begin{array}{l}\text { les } 40 \\
\text { ples }\end{array}$ \\
\hline
\end{tabular}


Table 9. Some validation results for Gaussian plume model predictions in both complex terrain and also under low wind

speed, inversion conditions

$\begin{array}{cc}\text { Conditions } & \text { Range of the ratio } \\ & \frac{\text { Predicted }}{\text { Observed }}\end{array}$

Review of a number of experiments conducted in complex terrain for plume centerline concentrations
$0.07-300$, individual measurements close to the source

$0.50-2,<2-15 \mathrm{~km}$ dowmwind of source

29

9 
than $-0.5^{\circ} \mathrm{C} / 100 \mathrm{~m}$. For smooth, unforested terrain, measured concentrations were lower than calculated values for atmospheric stability categories $E, F$, and $G$ by at least a factor of $2.3,1.3$, and 3.6 , respectively. Observed values were 20 to 40 times lower than predicted values for flat, forested terrain; 50 to 500 times lower for hilly, forested terrain.

\subsection{Other Atmospheric Dispersion Models}

As noted above, there are a number of conditions commonily encountered in radiological assessments for which the Gaussian plume model is not expected to apply. These include situations involving complex terrain or meteorology and long range transport. As a result, a large number of more complex, seemingly more realistic, dispersion models have been or are being developed for use in these obviously non-Gaussian situations. However, to run properly these models often require a much more extensive input data base than the Gaussian model, a computer with large storage capacity, and a long computer running time for each simulation desired. Thus, these conditions severely limit the practicality of using many of these more complex models in assessment activities. There is also a shortage of validation results for these models.

\subsubsection{Trajectory mode1s}

In a trajectory model, time- and space-dependent wind fields are used to calculate trajectories for either puffs or plume segments. 26 One example of such a model is that developed by the National Oceanic and Atmospheric Administration Air Resources Laboratories (ARL). 42 Predictions from this model have been compared with the data gathered at the Savannah River Laboratory ${ }^{43}$ with the results shown in Table 10 . The 
Table 10. Validation results for selected non-Gaussian atmospheric dispersion models

\begin{tabular}{|c|c|c|c|}
\hline Model & Conditions & $\begin{array}{l}\text { Range of the ratio } \\
\text { Predicted } \\
\text { Observed }\end{array}$ & Reference \\
\hline ARL & $\begin{array}{l}{ }^{85} \mathrm{Kr} \text { concentrations } 50 \\
\text { to } 150 \mathrm{~km} \text { downwind of } \\
\text { Savannah River Plant }\end{array}$ & $\begin{array}{l}0.5-2 \text {, seasonal average } \\
0.8-1.2 \text {, annual average } \\
0.5-2 \text {, weekly average, } 53 \% \\
\text { of samples } \\
0.1-10 \text {, weekly average, } 90 \% \\
\text { of samples } \\
0.5-2,2 \text { year average }\end{array}$ & $\begin{array}{l}39 \\
43\end{array}$ \\
\hline \multirow[t]{2}{*}{ ADPIC } & $\begin{array}{l}131 \text { I concentrations out } \\
\text { to approximately } 90 \mathrm{~km} \\
\text { at Idaho National } \\
\text { Engineering Laboratory }\end{array}$ & $\begin{array}{l}0.5-2,44 \% \text { of samples } \\
0.1-10,94 \% \text { of samples }\end{array}$ & 46 \\
\hline & $\begin{array}{l}41 \text { Ar concentrations out } \\
\text { to approximately } 25 \mathrm{kr} \text {. } \\
\text { at Savannah River Plant }\end{array}$ & $\begin{array}{l}0.5-2,61 \% \text { of samples } \\
0.1-10,98 \% \text { of samples }\end{array}$ & 46 \\
\hline IMPACT & $\begin{array}{l}\text { Complex terrain } \\
\text { Coastal situation }\end{array}$ & $\begin{array}{l}0.5-2,1 \text { hour iverage } \\
0.5-2,4 \text { hour average }\end{array}$ & $\begin{array}{l}28 \\
28\end{array}$ \\
\hline
\end{tabular}


ARL model does seem to perform somewhat better than the Gaussian model when applied to this same data set (Table 8 ). The ARL model has been used for assessing the impact of energy technologies on a regional ${ }^{44}$ and a conti ental ${ }^{45}$ scale.

\subsubsection{Particle-in-cell models}

Particle-in-cell (PIC) models are considerably more complex than the trajectcry model considered above. Particlo-in-cell models est imate atmospheric disfersion by calculating the trajectcries of many particles emitted as a function of time from a particular point source. The air concentration is calc lated by counting the number of particles per unit volume. ${ }^{26}$ One example of a PIC model is the ADPIC model developed at Lawrence Livermore Laboratory. 46 This model has been compared with short-term samples taken at the Idaho National Engineering Laboratory and the Savannah River '-aboratory (Table 10). Accurate specification of the wind direction afpeared to be the largest source of error in these comparisons. 46

\subsubsection{Grid models}

In grid models, numerical solutions to the three-dimensiunal advectiondiffusion squation are obtained on a grid network. One such model, IMPACT, has been applied to over a dozen locales involving complex terrain during the past two years. ${ }^{47}$ The IMPACT model has been compared with measurements in both complex terrain and a coastal environment (Table 10). For the same data sets, the maximum ringe of the ratio of the predicted to observed air concentrations for a Gaussian model was approximately 0.3 to 3 for the complex terrain and 0.25 to 4 for the coastal situation. 28 


\section{FOOD CHAIN MODELS}

The goai of most assessment models is the estimation of dose or exposure to human populations or single persons as a restit of sonie effluent release at a near or distant site. Models of aquatic transport or atmospheric transport generally can achieve only part of this goal (i.e., the calculation of effluent concentrations at some point distant from the source). Therefore, to account for an additional important aspect of the assessment goal, food chain models are needed. Food chain models can be classified as two types, terrestrial and aquatic. Basically, terrestrial food chain models consider foods produced, either directly or indirectly from the soil. Aquatic food chain models consider foods (fish) grown in some aquatic systern.

The uncertainties associated with predictions of food chain models will be discussed in this secticr. Terrestrial and aquatic food chain models will be examined separately.

\subsection{Aquatic Food Chain Models}

Models of dose to man via aquatic food chains are usually quite simple. ${ }^{48-51}$ Basically, 311 of these are compartmental models that are assumed to foilow first-order kinetics. For simplification and for chronic releases, the various pathways from water to the food for ma.l are often lumped into a single factor, called the bioaccumulation factor or concentration factor. Therefore, the aquatic food chain model for chronic releases can be generalized as:

$$
R=C_{W} \cdot B \cdot I \cdot D \text {, }
$$


where

$$
\begin{aligned}
& R=\text { radio!ogical dose to human, } \\
& C_{W}=\text { rad onuclide concentration in water, } \\
& B=\text { bioaccumulation factor in the food organism, } \\
& I=\text { intake rate by humans of food organism, } \\
& D=\text { dose conversion factor }(\text { rem/ } / \mathrm{C} i) .
\end{aligned}
$$

To our knowledge, no successful validatior. studies relating model predictions to observed data have been performed for aquatic food chain models. The reasoris for this lack include difficulties in measuring bioaccumulation factors, assessing human intake and internal dose, and sustaining a program long enough to achieve meaningful results. Because no such studies have been performed, the only manner in which the uncertainty in model output can be assessed is by investigating the characteristics of the input parameters.

The variation in the predicted radionuclide concentration, with the reservations discussed in Sect. 2 , is such that models may underpredict ty . $\therefore$ much as a factor of 2 and overpredict by a factor of 4 . Obviously, this range wuld directly affect the precision of the dose as estimated by Eq. (2).

The precision of the calculated dose would also be affected by uncertainty about the bioaccumulation factor. The process of assimilating radionuclides from the water by living organisms is complex and includes intake, incorporation into tissue, and excretion. Only when the radionuclide in the organism and the radionuclide in the water are in equilibrium, or when the time history of the organism and water are known, can 
the bioaccumulation factor be accurately measured. Some factors which affect the bioaccumulation factor are: the trophic level of the species; the chemistry of the water and the radionuclide; interaction between sediment and water; nutrient levels in water; and temperature and numerous other chemical, physical and biological factors. 51 Some or all of these characteristics may combine to cause the calculated bioaccumulation factor to vary as much as $10^{4}$ in different aquatic environments.

A recent study of fish i nsumption by individuals within regions of the United States generated data that describe the variability of human dietary intake of fish. 52 The consimption patterns for several age groups and nine regions of the United States were delineated for freshwater finfish, salt water finfish and shellfish. For the adult group, the maximum individual intake of fresh-water finfish was 108 times as much as the mean for the more than 21,000 people surveyed. For salt vater finfisi: and shellfish, the maximum intake was 17 and 37 times the mean, respectively. Presumably, a larger sampling of the population would result in even higher maximum consumption rates. If so, the ability to prefict accurately dose to a maximum individual becomes more difficult, and the variance about the mean intake increases.

In the unlikely event that all of the extreme factors listed in the preceeding paragraphs were to occur simultaneously, the result would be a huge overprediction of the central tendency of the dose. An overprediction of pollutant concentration by a factor of 4 , of bioaccumulation factors by as much as 500, and of fish consumption by 100 , could result in a given prediction that was as much as 200,000 times as great as the 
actual dose. It is evident that the amount of variance in the distribution of potential doses is very large indeed.

The potential uncertainty associated with a predicted dose or exposure can be better quantified by studying the distribution of the input parameters as stated earlier, or by comparing the predictions of an aquatic food chain model with actual measurements. The latter is probably not achievable. The former could be accomplished if the data base for each input parameter is sufficiently detailed.

Using reports that estimate the variance of observed values for the bioaccumulation factor and intake rate, we have attempted to make such a calculation for an aquatic food chain model as represented by Eq. (2) but excluding considerations of dose. We are assuming for the factors B and I that the model will consist of default or non-site-specific multipliers. If this is the case, then the uncertainty about the prediction of $R$ for any given concentration will include the uncertainty surrounding $B$ and $I$ in addition to the variance in predicting a given concentration of pollutant in water and predicting dose. Further assuming that B and I are lognormally distributed, the total variance in the prediction that results from those parameters can be shown to be: 53,54

$$
\sigma_{T}^{2}=\sigma_{B}^{2}+\sigma_{1}^{2}
$$

where

$\sigma_{B}^{2}=$ variance of the logarithms of the observed bioaccumulation factors, $\sigma_{I}^{2}=$ variance of the logarithms of the observed intake rates, $\sigma_{T}^{2}=$ variance of the distribution of $B \cdot 1$. 
By calculating values of $\sigma^{2}$ for $B$ and I, substituting them into Eq. (3), we can calculate the uncertainty asscciated with the prediction of pollutant intake given aii accurate estimate of the water concentration. Becaise data for ${ }^{137}$ Cs were available for bioaccumulation factors, an example of the uncertainty in calculating pollutant exposure through the aquatic pathway to an adult follows.

The summary of bioaccumulation factors published by Vanderploeg et al. ${ }^{55}$ lists eight groups of values $\mathrm{fc}^{\mathrm{r}}$ the uptake of ${ }^{137} \mathrm{Cs}$ by freshwater finfish. All of these values were either for fallout or some chronic release of ${ }^{137} \mathrm{Cs}$ into the water body of interest. The arithmetic means of these eight groufs were shown to be lognormally distributed. 56 The mean, $\mu_{B}$, and standard deviation, $\sigma_{B}$, of the logarithms of the eight groups were 7.2 and 0.86 , respectively. These translate to a median bioaccumulation factor for ${ }^{137}$ Cs of 1340 and an arithmetic mean of 1940.

The uncertainty term for intake, $\sigma_{I}$, was calculated from a survey of the eating habits of over 20,000 people. 52 Again assuming a lognormal distribution, the standard deviation of the logs was found to be approximately 1.2. Coupled with a mean of the loas of -1.2 this represents a distribution with a geometric mean of $0.30 \mathrm{~kg} /$ year and an arithmetic mean of $0.85 \mathrm{~kg} /$ year.

By substituting $\sigma_{B}=0.86$ and $\sigma_{I}=1.44$ into Eq. (3) we can calculate a value of $\sigma_{T}=1.68$. The impact of such a value of $\sigma_{T}$ can best be visualized by calculating a one-tailed $95 \%$ confidence interval for the value of $\mu_{T} \mathrm{pCi} /$ year for a given water concentration with the following formulas: 
95\% confidence limit $=\exp \left(\mu_{T}+1.65 \sigma_{T}\right)$,

99\% confidence limit $=\exp \left(\mu_{T}+2.33 \sigma_{T}\right)$.

If this is done, we find that for any value of ${ }^{\prime} T$, the $95 \%$ confidence interval upper tound is 15.9 times exp $\mu_{T}$. Similarly, the $99 \%$ confidence limit would be 49.8 exp $\mu_{T}$.

The confidence limits can be interpreted as follows. If we choose default or generic values for the bioaccumulation factor (B) and the intake rate of fish (I), and if the variance about those factors is governed by the variance in the distribution of estimated Bs and Is, then we can predict the ${ }^{137}$ Cs exposure to an adult from any concentration of ${ }^{137} \mathrm{Cs}$ in water to within a factor of 16 with $95 \%$ confidence and within a factor of 50 with $99 \%$ confidence. Stated another way, if one hundred estimates of ${ }^{137}$ Cs exp: : ure to an adult are made under similar conditions for a given concentration of water, the actual exposure will exceed 16 times the calculated exposure in only five trials and will exceed 50 times the calculated exposure only once. For the other nuclides, age groups, and organs, the amount of overprediction may be larger or simaller.

The ability of an aquatic ford chain model to predict a dose is also a function both of the abilily to predict some water concentration and to predict dose given an exposure. The reader should refer to the earlier section on aquatic transport models for a discussion of the ability of such models to predict accurately concentrations of pollutanes in waters or sediment. A discussion of the difficulties in predicting dose, generally, can be found elsewhere. 57 A discussion of the uncertainty in a dose conversion factor is given for ${ }^{131} I$ by Dunning. 58 
In general terms, we can examine the ability to predict accurately concentration in water, bioaccumulation, intake rate, and dose conversion factor. Using published scientific judgments, we surm. sed that the range of uncertainty in each model type was such that dose could be overpredicted or underpredicted by tens or hundreds of thousands.

Utilizing data which specifically pertain to the prediction of ${ }^{137}$ Cs exposure to an adult via the aquatic food chain, we calculated that for fish grown in a given concentration of ${ }^{137} \mathrm{Cs}$ in water we would overpredict the exposure by less than a factor of 15.9 in $95 \%$ of the cases. Given these results, improvements in the data bases for bivaccumulation, food intake by region, age, and sex, and for factors entering into calculation of the dose conversion factor can narrow the width of the confidence interval considerably.

The comparison of the generalized uncertainty implied by looking at ranges with that of the estimate of uncertainty embodied in the $95 \%$ confidence interval emphasizes the danger of propagating uncertainty by examining only the ranges. To be meaningful, estimates of variance specific to given parameters need to be examined.

\subsection{Terrestrial Food Chain Models}

Several models exist that were designed to predict the dose to humans via the terrestrial food chain. ${ }^{49,59-62}$ Most of these (F00D, GRONK, NRC Peg. Guide 1.109) are steady-state models applicable to chronic contamination situations. The TERMOD model, ${ }^{61}$ however, is a linear compartment model. If time-dependent parameters were to be in:erted into TERMOD flows, the model could theoretically simulate doses following an acute release. 
As with the aquatic food chain models discussed in the prev ous section, there are few data available with which to compare model predictions for the purpose of validating the model. However, it is appropriate to estimate the uncertainty embodied in the model predictions by analyzing the variances of the model input parameters. Such a study has recently been completed for the transport of ${ }^{131}$ I through the air-grass-cow-milkthyroid pathway for infants. 63

The model used in that study took the form:

$$
R=v \cdot k \cdot v_{0} \cdot I / \lambda_{\text {eff }} \cdot Q \cdot f_{s} \cdot F_{m} \cdot f_{p} \cdot U \cdot D,
$$

where

$$
\begin{aligned}
& x=\text { equilibrium air concentration }\left(\mathrm{pCi} / \mathrm{m}^{3}\right) \text {; } \\
& k=a \text { unit conversion factor }(86400 \mathrm{sec} / \text { day }) \text {; } \\
& V_{D}=a_{3} \text { air concentration to pasture grass transfer factor } \\
& \left(\mathrm{m}^{3} / \mathrm{kg}\right. \text {, dry wt. - sec); } \\
& 1 / \lambda_{\text {eff }}^{\prime}=T_{\text {eff }} / \ln 2 \text { = effective mean-time on pasture vegetation (days); } \\
& Q=\text { total daily dry matter intake of a dairy cow ( } \mathrm{kg} / \text { day); } \\
& f_{s}=\text { fraction of the total dry matter intake composed of fresh } \\
& f_{p}=\text { fraction of a year that dairy cows receive fresh forage; } \\
& F_{m}=\text { intake-to-milk transfer factor (day/liter); } \\
& U=\text { annual milk consumption rate (liters/year); } \\
& D=\text { thyroid dose conversion factor for infants, ages } 0.5 \text { to } \\
& 1.5 \text { years, (mrem/pCi ingested); }
\end{aligned}
$$


$R=$ dose comitment (mrem/year) to the thyroid.

The methods used for the uncertainty analysis of the model represented by Eq. (5) included searching the literature for appropriate data for each parameter, testing for lognormality, and calculating distributional statistics, $\mu$ and $\sigma$, for the model outpui, R. As discussed earlier, when dealing with a multiplicative chain of lognormal parameters, the variance of the logarithms of the model output can be estimated by suming similar terms for each input parameter: ${ }^{53,54}$

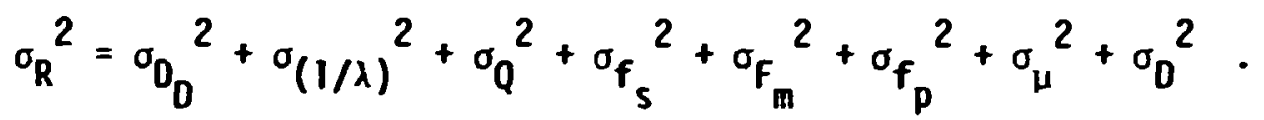

No terms are included for $x$ or $k$ because these factors are a site-specific measurement i $d$ a constant, respectively.

The $\sigma$ value found by Hoffman ${ }^{63}$ for each parameter listed in Eq. is: $V_{D}, 4.8 E-2 ; 1 / \lambda, 1.4 E-1 ; Q, 1.2 E-1 ; f_{s}, 2.4 E-1 ; f_{p}, 4.1 E-1 ; F_{m}$, $5.5 \mathrm{E}-1 ; \mathrm{U}, 2.0 \mathrm{E}-1 ; 0,7.0 \mathrm{E}-1$. When these values are entered into Eq. (6), the rasulting estimate of the value of $\sigma_{R}=1.046$. The value of $\sigma_{R}$ can be substituted into $\sigma_{T}$ in Eq. (4) to calculate a one-tailed 95\% confidence bound for the median value of $R$ for a given air concentration. In this case, the $95 \%$ confidence bound would be 5.6 times exp $\mu$. These ranges are somewhat narrower than similar ranges calculated for aquatic food chain models in the previous section. This difference may be explained by the fact that the largest contributor to the variance in the aquatic section, freshwater finfish intake rate, was quantified for children 1-11 years old but was applfed with a dose conversion factor for infants. In any event, the analyses for neither the aquatic, nor 
the terrestrial, food chains can be considered to be indicative for the variance expected for other nuclides, age groups, or critical organs.

\section{SUMTARY AND CONCL'JSIONS}

\subsection{Aquatic Transport Models}

The one-dimensional models of G:oyna and his co-workers ${ }^{3,4}$ which have the ability to include sorption effects, te $J$ to underpredict the maximm concentration of radionuclides in the water of a model river. However, in the reports we examined, the prediction was never less than $65 \%$ of the observed maximum concentration. Raridon et al. ${ }^{5}$ modified the Shih-Gloyna model ${ }^{3}$ and predicted concentration downstream from a mercury release site. The model of Raridon et al. overpredicted concentration, but never more than a factor of 2.0 .

The two-dimensional (1ongitudinal-vertical) model of Onishi, SERATRA showed some accuracy in predicting the concentrations of ${ }^{137} \mathrm{Cs}$ and ${ }^{98} \mathrm{Sr}$ in the $\mathrm{Cl}$ inch River ${ }^{6}$ and ${ }^{65} \mathrm{Zn}$ in the Columbia River. ${ }^{7}$ The SERATRA model tended to underpredict the observed concentrations, but the largest discrepancy was an underprediction by a factor of 4 . However, so few field data were published by Onishi ${ }^{6,7}$ that the SERATRA model should probably be ccnsidered only partially validated at best.

The two-dimensional (longitudinal-transverse) model of Jackman and Yotsukura ${ }^{10}$ predicted river temperature to within $2^{\circ} \mathrm{C}$ of the observed temperature in a number of rivers at various distances and times downstream of a thermal input source. Yotsukura and his co-workers 8,9 "verified" the solute transport version of their models by varying model parameters to achieve the best fit of the prediction curve to the observation curve; when the varied parameter agreed well with published values 
of the same parameter, they considered their model "verified." In our judgnent, the Yotsukura model can probably predict observed downstream and transverse solute concentrations to within about $30 \%$ under most conditions.

The FETRA model of Onishi and Nise ${ }^{14}$ underpredicted both particulate kepone concentration of sediment and sediment concentration of water. However, the prediction to observation ratio was never lower than 0.63 for kepone or 0.33 for sediment. Predictions of dissolved kepone concenirations in water were not compared to observed dissolved kepone.

In conclusion, we can say that the state of the art of aquatic transport modeling has progressed beyond the point where ir.vestigators would have been satisfied with order of magnitude accuracy. None of the models we reviewed overpredicted by more than a factor of 2 or underpredicted by more than a factor of 4 . Whether the current level of ability to predict aquatic transport of materials is adequate will need to be judged by policymakers. However, as environmental release or environmental concentration standards tighten with time, it is likely that more accuracy will be needed.

\subsection{Atmospheric Transport Models}

A summary of the estimated uncertainty associated with predictions made by the Gaussian plume atmospheric dispersion model has been presented (Table 5). No attempt was made to complle all validation measurements found in the literature. Measurement results were presented, however, which indicate that the "scientific judgement" estimates of uncertainty presented are quite reasonable. Limited validation results were also 
presented for other, more complex, dispersion riodels. More data are needed to perform a stastical analysis of the uncertainty assuciated with any atmospheric dispersion model. Such data will also allow a clearer specification of when complex morlels should supplement the comon Gaussian plume model in radiological assessments.

\subsection{Food Chain Models}

Two simple multiplicative foodcha in models were analyzed. The variance of predictions is estimated by suming the variance of the logarithms of each lognormal input parameter. For the aquatic foodchain model of the water-fish-human for ${ }^{137}$ Cs pathway, the one-tailed $95 \%$ confidence interval of the predicted exposure is 16 times the median exposure for a given concentration in water. For the terrestrial model of the air-grass-cow-milk-infant-thyroid pathway for ${ }^{131} 1$, the onetailed $95 \%$ confidence interval of the predicted dose is 5.6 times the median dose for a known pollutant concentration in air. 


\section{REFERENCES}

1. F. 0. Hoffman, 0. L. Shaeffer, C. H. Miller, and C. T. Garten, Jr., (eds.), Proceedir.js of a Workshop on the Evaluation of Models Ised for the Environmental Assessment of Radionuclide Releases, USDOE Report CONF-770901, NTIS, April 1978.

2. E. F. Gloyna (Chairperson), Hydrologic Transport of Radionuclides, pp. 33-54, Proceedings of a Workshop on the Evaluation of Models Used for the Environmental Assessmert of Radionuclide Releares, $\epsilon^{A}$ by F. 0. Hoffman, D. L. Shaeffer, C. W. Miller, and C. T. Garten, Jr., CONF-770901, April 1978.

3. C. S. Shih and E. F. Gloyna, Radioactivity Transport in Water-Mathematical Model for the Transport of Radionucliaes, CRHR-18, Center for Research in Water Resources, The University of Texas, Austin, Texas, June 1, 1967.

4. N. E. Armstrong and E. F. Gloyna, Radioactivity Transport in WaterNumerical Solutions of Radionuclide Transport Equations and Role of Plants in Sr-85 Transport, CRWR-23, Center for Research in Water Resources, The University of Texas, Austin, Texas, January 1978.

5. R. J. Raridon, M. T. Mills, and J. W. Huckabee, Computer Model for Chemical Exchange in the Stream System, Pp. 284-291 in Proceedings of the First Annual NSF Trace Contaminants Conference, Oak Ridge National Laboratory, August 8-10, 1973, CONF-730802, 1973.

6. Y. Onishi, Finite Element Models for Sediment and Contaminant Transport in Surface Waters-sransport of Sediments and Radionuclides in the Clinch River, BNHL-2227, July 1977.

7. Y. Onishi, Mathematical Simulation of Sediment and Radionuclide Transport in the Columbia River, BNWL-2228, August 1977.

8. N. Yotsukura and E. D. Cobb, Transverge Diffusion of Solutes in Nat'ural Strecms, U. S. Geological Survey Professional Paper 582-C, U.S. Goveriment Printing Office, Washington, D.C., 1972.

9. N. Yotsukura and W. W. Sayre, Transverse Mixing in Natural Channels, Water Resour. Res. 12(4): 695 (August 1976).

10. A. P. Jackman and N. Yotsukura, Thermal Loading of Natural Streams, U.S. Geological Survey Professional Paper 991 , U.S. Government Printing Office, Washington, D.C., ?977.

11. U.S. Nuclear Regulatory Commission (USNRC), Estimating Aquatic Disperoion of Effluents from Accidental and Routine Reactor Releases for the Purpose of Implementing Appendix I, Regulatory Guide 1.113 (Apri1 1977). 
12. Y. Onishi, P. A. Johanson, R. G. Baca, and E. L. Hilty, Studies of Columbia River Water Quality, Development of Hathematical Models for Sediment and Radionuclide Transport inaiysis, USDOE Report ENUL-B-452, NTIS, January 1976.

13. Y. Onishi and R. M. Ecker, Mathematical Simulation of Transport of Kepone and Kepone-Laden Sediments in the James River Estuary, Proceedings of Kepone Seminar II, Easton, Md., September 1977.

14. Y. Onishi and S. E. Wise, Mathematical Simulation of Transport of Sediment and Kepone in the James River Estuary, PNL-2731, September 1978.

15. F. A. Gifford, Jr., An Outline of Theories of Diffusion in the Lower Layers of the Atmosphere, in Meteorology and Atomic Energy-196E, ed. by D. Slade, Chap. 3, USAEC Report TID-24190, NTIS, July 1968.

16. F. O. Hoffman, C. W. Miller, D. L. Shaeffer, C. T. Garten, Jr., R. H. Shor, and J. T. Ensminger, 4 Compilati $\because$ of Documented Computer Codes Applicable to Envirommental Assessment uf rinoactivity Releases, USEROA Report ORIL/TM-5830, Oak Ridge National Laboratory, NTIS, April 1977.

17. F. 0. Hoffman, C. W. Miller, D. L. Shaeffer, and C. T. Garten, Jr., A Compilation of Computer Codes for the Assessment of Radionuclides Released to the Environment, Nucl. Saf., 18(3):343-354 (May-June 1977).

18. F. Pasquill, Atmospheric Diffusion, 2nd Edition, John Wiley and Sons, New York, 1974.

19. A. H. Weber, Atmospheric Dispersion Parameters in Gaussian PIzone Modeling Part I. Review of Current systems and Possible Future Developments, USEPA Report EPA-600/4-76-030a, NTIS, July 1976.

20. F. A. Gifford, Jr., Turbulent Diffusion-Typing Schemes: A Review, Nucl. Saf., I7(1):68-86 (January-February 1976).

21. K. J. Vogt, Empirical Investigations of the Diffusion of Waste Air Plumes in the Atmosphere, Nucl. Tectinol., 34(6):43-57 (June 1977).

22. S. R. Hanna, G. A. Briggs, J. Deardorff, B. A. Egan, F. A. Gifford, and $F$. Pasquill, AMS Workshop on Stability Classification Schemes and Sigma Curves-Summary of Recommendations, Bul. Am. Meteorol. Soc., 58(12): 1305-1309 (December 1977).

23. M. M. Pendergast, Estimating Dispersion Coefficients from Meteorological Data, USERDA Report DP-MS-76-65, Savannah River Laboratory, NTIS, 1976 .

24. C. W. Miller, A Critique of the Determination of Atmospheric Stability Categories for Assessing Airborne Releases of Radionucilides, Health Phys. 34(5):489-492 (May 1978). 
25. C. H. Miller, C. H. Little, F. 0. Hoffman, Validation of Turner Workbook Normalized Air Exposure Predictions for Surface Level Releases Using Hanford Dispersion Data, pp. 95-102 in Preprint Voizme, Ame:ican Heteorological Society Fourth symposium on Thu bulence, Diffusion, and Air Follution, Janvary $25-28,2973$, Peno, llevada.

26. T. V. Crawford (Chairperson), Atmospheric Transport of Radionuclides, Pp. 5-32 in Proceedings of a Workstop on the Evaluation oj Hodels Used for the Environmental Assessment of Radionuclide Releases, ed. by F. O. Hoffman, D. L. Shaeffer, C. H. Miller, and C. T. Garten, Jr., USDOE Report CONF-770901, NTIS, April 1978.

27. G. A Briggs, Plzome Rise, AEC Critical Review Series, USAEC Report TID-25075, NïIS, 1969.

28. A. Faberick, R. Sklarew, and j. Wilson, Foint Source Modeling, Form and Substance, inc., Kestlake Village, California, September 1977.

29. R. C. Koch, W. G. Biggs, P. H. Hwang, I. Leichter, K. E. Pickering, E. R. Sawdey, and J. L. Swift, Power Plant stack Plumes in Complex Terrain: An Appraisal of Cur:ent Researcin, USEPA Report EPA 600/ 7-77-020, Environmental Sciences Research Laboratory, NTIS, March 1977.

30. G. R. Hilst, Plume Model Validation, Report EA-917-SY, Electric Power Research Institute, Pain Alto, California, October 1978.

31. D. C. Guzewich and W. J. B. Pringle, Validation of the EPA-PTMTP Short-Term Gaussian Dispersion Model, J. Air Pollut. Control Ascoc., $27(6): 540-542$ (June 1977).

32. C. W. Miller and R. E. Moore, Verification of a Methodology for Computing Ground-Level Air Concentration of $\mathrm{SO}_{2}$ and Suspended Particulates for Both Point and Dispersed Sources, pp. 321-326 in Preprint Volume, Joint Conference on Applications on Air Pollution Meteorolozy, November 28-December 2, 1977, Salt Lake City, Utah, American Meteorological Society, Boston.

33. C. W. Miller, An Application of the ATDL Simple Dispersion Model, J. Air PcILut. Control A880c., 28(8):798-800 (August 1978).

34. C. V. Gogolak, Comparison of Measured and Calculated Radiation Exposure from a Boiling Water Reactor Plione, USAEC Report hASL-277, Heaith and Safety Laboratory, NTIS, September 1973.

35. J. A. Martin, Jr., Dose Modeling for Nuclear Facilities, pp. 234240, in Proceerling 3, 6th Annual National Conference on Radiation Control, April 28-May 2, 1974, San Antonio, Texas, USDHEW Publication (FDA) 7b-8010, U.S. Public Health Service, NTIS, October 1974. 
36. J. E. Partridge, J. A. Broadway, C. R. Phillips, S. T. Windham, and C. B. Nelscn, Air Pathuxy Exposure Model Validation Study at the Honticelzo Huclear Generatin. Plant, USEPA Report EPA-520/5-76-015, Office of Radiation Programs, NTIS, September 1976.

37. M. M. Pendergast, A. L. Boni, G. J. Ferber, K. Telegadas, Measured Weekly ${ }^{85} \mathrm{Kr}$ Concentratione kithin $150 \mathrm{~km}$ of the Savannah River Plant (:urch 1975 through August 1976), USDOE Report DP-1486, Savannah River Laboratory, NTIS, January 1979.

38. M. M. Pendergast, A Comparison of Observed Average Concentrations of ${ }^{85} \mathrm{Kr}$ with Calculated Values Obtained froin a Wind Rose Model a ?d a Time-Dependent Trajectory Model, pp. 253-254 in Preprint Volume, American Meteorological Societs/Air. Pollution Control Association Joint Conference on Applications of Air Pollution Meteorology, November 29-December 2, 1977, Salt Lake City, Utah.

39. K. Telegadas, G. J. Ferber, J. L. Heffter, and R. R. Draxler, Calculated and Observed Seasonal and Annual Krypton-85 Concentrations at $30-150 \mathrm{~km}$ from a Point Source, 4 tmos. Environ., 12:1769-1775 (1978).

40. M. M. Pendergast, Model Evaluation for Travel Distances $25-140 \mathrm{~km}$, pp. 648-651 in Preprint Volume, American Neteorologisal Society Fourth Symposizm on Turbulence, Diffusion, and Air Pollution, January 15-18, 1979, Reno, Nevada.

41. i. Van der Hoven, A Survey of Field Measurements Under Low-WindSpeed Invers:ion Conditions, IJucl. Saf., 17(2):223-229 (March-April 1976).

42. J. L. Heffter and A. D. Taylor, A Regional-C mtinental Scale Transport, Diffusion, and Deposition Mode 2 , Part I: Traiectom, Model, NOAA Technical Memorandum ERL-ARL-50, Air Resource:; Laboratories, Silver Spring, Maryland, NTIS, June 1975.

43. J. L. Heffter, G. J. Ferber, and K. Telegadas, Verification of the ARL Transport and Dispersion Model at 30-150 km, pp. 372-375 in Preprint Volume, American Meteorological Society Fourti Symosium on Turbulence, Diffusion, and Air Pollution, January 15-18, 1979, Reno, Nevada.

44. C. L. Begovitch, B. D. Murphy, and C. J. Nappo, Jr., RETADD: A Regicnal Trajectory and Diffusion-Depusition Mdel, USDOE Report ORNL/TM-5859, Oak Ridge National Laboratory, NTIS, June 1978.

45. C. C. Travis, A. P. Watson, L. M. McDowell-Boyer, S. J. Cctter, M. L. Randolph, and D. E. Fields, A Ratiological Assessment of Radon-222 Released from Uranizon Mills and Other llatural and Troshnologically Enhanced Sources, USNRC Report NUREG/CR-0573, ORNL/ NUREG-55, Oak Ridge Nationai Laboratory, IITIS (in press). 
46. R. Lange, ADPIC-A Three-Dimensional Particle-in-Cell Model for the Dispersal of Atmospheric Pollutants and Its Comparison to Regional Tracer Studies, J. Appl. Meteorol., 17:320-329 (March 1978).

47. R. C. Sklarew and V. A. Mirabella, Experience in IMPACT Modeling of Complex Terrain, pp. 205-212 in Preprint Volione, American Meteorological Society Fourth Symposiun on Turbulence, Iiffusion, aria Air Pollution, January 15-18, 1979, Reno, Nevada.

48. J. K. Soldat, D. A. Baker, and J. P. Corley, Applications of a General Computational Mode? for Composite Environmental Radiation Doses, pp. 483-498 in Environmental Behaviour of Radionuclides Released in the Nuclear Industry, IAEA, Vienna, 1973.

49. U.S. Nuclear Regulatory Commission, Regulatory Guide 1.109: Calculation of Annual Doses to Man from Routine Releases of Reactor Effluents for the Purpose of Evaluating Compliance with iO CFR Part 50, Appendix I, Revision 1 (October 1977).

50. D. L. Shaeffer and E. L. Etnier, AQUAMAN-A Computer Code for Calculating Dose Commitment to Man from Aqueous Releases of Radionuclides, USDOE Report ORML/TM-6618, Oak Ridge National Laborat.ory, NTIS, February 1979.

51. I. L. Ophel (Chairperson), Aquatic Food Chain Transport of Radionuclides, pp. 73-84 in Proceedings of a Workshop on the Evaliation of Models Used for the Environmental Assessment of Radionuclide Releases, ed. by F. 0. Hoffman, D. L. Shaeffer, C. W. Miller, and C. T. Garten, Jr., USDOE Report CONF-770901, NTIS, April 1978.

52. E. M. Rupp, Health and Safety Research Division, Oak Ridge National Laboratory, Oak Ridge, Tennessee, personal communication to $C$. A. Little, March 1979.

53. D. L. Shaeffer, A Model Evaluation Methodology Applicable to Environmental Assessment Models, Ecological Modeling (accepted for publication, March 1979).

54. J. Aitchison and J. A. C. Brown, The Lognomal Distribution, Cambridge University Press, Cambridge, 1976.

55. H. A. Vanderploeg, D. C. Parzyck, W. H. Wilcox, J. R. Kercher, and S. V. Kaye, Bioacmomulation Factors for Radionuclides in Freshwater Bista, USDOE Report ORNL-5002, Oak Ridge National Laboratory, NTIS, November 1975.

56. F. O. Hoffman, Bioaccumulation Factors for Freshwater Fish, Bin, in A Statistical Analysis of Selected Parmeters for Predicting Food Chain Transport and Intermal Dose of Radionuclides, ed. by F. 0. Hoffman and C. F. Baes III, Section 3.10, USNRC Report ORNL/ NUREG/TM-282, Oak Ridge National Laboratory, NTIS, 1979 (in press). 
57. P. S. Rohwer (Chairperson), Internal and External Dosimetry, pp. 99-122 in Proceedinas of a Workshop on the Evaiuation of :1odels Used ior the Environmentai Assessment of Radioruclide Releases, ed. by F. O. Hoffman, D. L. Shaeffer, C. H. Mill s, and C. T. Garten, Jr., CONF-770901, April 1978.

58. D. E. Dunning, ${ }^{131} I$ Ingestion Thyroid Dose Conversion Factor for Infants, in A Statistical Analysis of Selected Parameters for Prodicting Food Chain Transport and Intemial Dose of Radionueitides, ed. by F. 0. Hoffman and C. F. Baes III, Section 3.12, USNRC Report ORNL/NUREG/TM-282, Oak Ridge Hational Laboratory, NTIS, 1979 ( $\mathrm{i}_{i .}$ press).

59. D. A. Baker, G. R. Hoenes, and J. K. Soldat, Food-An Interactive Code to Calculate Internal Radiation Doses from Contaminated Foor Products, in Environmental Modeling and Simulation, Proceedings of a Conference held in Cincinnati, Ohio, April 20-22, 1976, U.S. Environmental Protection Agency, Washington, D.C., 1976.

60. J. K. Soldat, N. M. Robinson, and D. A. Baker, NoceZs and Computer Codes for Evaluating Environmental Radiation Doses, USDOE Report BNWL-1754, Battelle Pacific Northwest Laboratories, NTIS, 1974.

61. R. S. Booth, S. V. Kaye, and P. S. Rohwer, A Systems Analysis Methodology for Predicting Dose to Man from a Radioactively Contaminated Terrestrial Enviroment, in Proceedings of the Thiro National Sumposium on Radioecoloyy, Dak Ridge, Tennessee, May 1012, 1971, USAEC Report CONF-710501, NTIS, 1971.

62. J. K. Soldat (Chairperson), Terrestrial Food Chain Transport of Radionuclides, pp. 85-98 in Procerdings of a Worksinop on the Evaluation of Hodels Used for the Environmental Assessment of Radionuclide Releases, ed. by F. 0 . Hoffman, D. L. Shaeffer, C. W. Miller, and C. T. Garten, Jr., CONF-770901, April 1978.

63. F. 0. Hoffman, Prediction of the Transiurt of ${ }^{131}{ }^{1}$ Through the Grass-Cow-Milk Pathway and the Subsequent Dose to an Infant's Thyroid, in A Statistical Analysis of Selected Parometers for Predicting Food Chain Transport and Interma Dose of Radionuciides, ed. by F. 0. Hoffman and C. F. Baes III, Section 4, USNRr. Report ORNL/NUREG/TM-282, Oak Ridge National Laboratory, NTIS, 1979 ( in press). 